\title{
THE ELECTROLYTE BALANCE IN ACUTE GOUT ${ }^{1}$
}

\author{
By JOHN H. TALBOTT, BERNARD M. JACOBSON AND S. A. OBERG \\ (From the Medical Clinic of the Massachusetts General Hospital and the Fatigue Laboratory, \\ Harvard University, Boston)
}

(Received for publication March 29, 1935)

The classification of gout as a disturbance of metabolism is probably as old as the recognition of such disorders in medicine. The ancient physicians who wrote about podagra suggested a disorder of normal metabolism when they attributed the cause of the disease to a disturbance of the humours of the body. But it was not until 1797 that Wollaston (1) offered experimental evidence for the validity of this assumption when he identified sodium urate crystals in the material obtained from the tophi of patients with gout. Some time later Garrod (2) extended this observation and noted an increased concentration of uric acid in the blood from patients similarly afflicted. The classification of uric acid as a purine body by Emil Fischer (3) completed one phase of the pathologic physiology that confirmed the earlier impressions that gout should be placed in the category of metabolic dyscrasias.

It is usually granted by contemporary observers that an integral part of the pathogenic process in gout is a disturbance of uric acid metabolism. Most arguments that have arisen about this subject have been over the question as to whether the disturbance is one of uric acid formation, excretion, or destruction, rather than a denial of the major premise. Exceptions to this statement have been made by the German investigators Grafe (4) and Thannhauser (5), who have advanced the possibility that the disturbance of uric acid metabolism in gout may be secondary to a pathologic process more general in effect.

The data presented in this paper offer support to the hypothesis that gout may be a disturbance of the equilibrium of the body more widespread in scope than a dysfunction of the uric acid metabolism. We accept the classification of gout as a metabolic disease, but our reasons for this acceptance are based upon data only casually related to

\footnotetext{
1 Presented in abstract form at the meeting of the American Society for Clinical Investigation, April 30, 1934.
}

a disturbance of purine metabolism. These data have been obtained from an extended study of the mineral and water exchange associated with attacks of acute gout in the patient F. M. We have also included confirmatory data obtained from a study of a second patient, $\mathrm{K}$. H.

\section{METHODS}

The protocols of the two cases studied are presented at the end of this communication together with the records of the food ingested. During the periods of study in the metabolism ward of the Massachusetts General Hospital, the patients were given a low-purine diet of constant amount. The food was purchased in 5-day lots according to the method of Atchley, Loeb et al. (6). Onehalf of a duplicate day's diet from each lot was weighed, dried and analyzed. On the days of severe symptoms all of the food was not eaten, and the fluid intake was increased. For these days, food equal to the amounts consumed was taken from the 5-day lots; it was dried, analyzed, and the data with respect to intake corrected accordingly. The urine was collected under toluol and kept in the ice chest. It was partitioned and analyzed each 24 hours. The stools, which were collected in periods corresponding to the symptoms, were dried and analyzed similarly to the diets. Rectal temperatures were recorded 4 times a day.

The methods employed for the analyses of the blood, and the correction of the concentration of the constituents of the serum to $\mathrm{pH}_{\mathrm{s}}=7.45$, have been described in most instances elsewhere (7). The uric acid was determined according to the method of Folin (8) on plasma or unlaked whole blood. The inorganic base was determined on a portion of urine, stool, or diet, treated with a few drops of $\mathrm{H}_{2} \mathrm{SO}_{4}$, ashed in a platinum evaporating dish and taken up in $0.5 \mathrm{~N} \mathrm{HCl}$. Serum was ashed with $\mathrm{HNO}_{3}, \mathrm{H}_{2} \mathrm{SO}_{4}$, and superoxol in a silica tube, and the sodium was determined ac- 
cording to the method of Butler and Tuthill (9). Potassium was determined by the method of Jacobs and Hoffman (10). The $\mathrm{pH}$ of the urine was determined colorimetrically by the bi-color method of Hastings et al. (11), and the titratable acid according to the method of Folin (12).

\section{OBSERVATIONS}

The experimental data presented at this time were obtained from two patients suffering from recurrent attacks of acute gout. The patient F. M. was under our clinical supervision for more than 22 months. During this time he had 50 attacks of acute gout, 21 of which were observed while he was on a metabolic regime. The significant changes observed in the attack described in this paper correspond qualitatively to the changes observed during the other 20 attacks. The patient $\mathrm{K}$. H. was observed over a period of 9 weeks, and during this time she had 7 attacks of acute gout.

The duration of study of these patients was very long, and all of the data accumulated could not be adequately treated by the methods in common use. It was necessary and convenient, therefore, to divide the long periods of study. The frequent occurrence of attacks of acute symptoms allowed us to employ these attack periods as points for division. The selection of one phase of an attack, as judged from the clinical condition of the patient, is not difficult and may be repeated for each attack. The time elapsed from one phase of an attack to the same phase of a following attack has been called by us a cycle. This cycle may be subdivided into 3 periods, following the scheme suggested by Duckworth (13). These are the prodromal, attack and recovery periods, respectively. The prodromal period follows the last days of the recovery from an attack and includes the first hours or day of mild symptoms of the subsequent attack. The usual duration of the prodromal period is from 2 to 4 days. With the progression of symptoms the attack period begins and the patient is confined to bed. When the symptoms reach their maximum, specific medication is required. Colchicin was the specific drug given during the attacks herein described. This drug was given in divided doses over several hours and in a sufficient amount to induce diar-

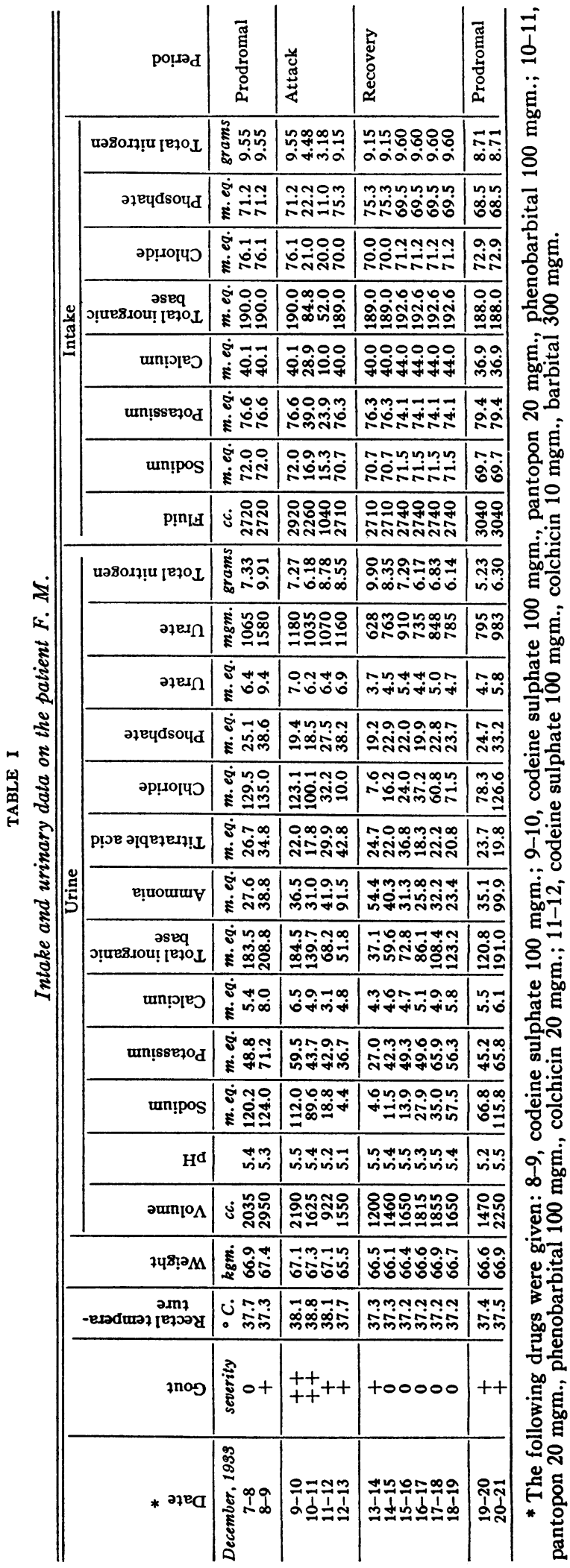


rhea. With the onset of diarrhea, the symptoms subside and the attack period is considered over. The recovery period extends from the subsidence of symptoms to the prodromal period of the next cycle. The apparent merging of the recovery period of one cycle with the prodromal period of the following cycle prevented us from obtaining a normal or control period. Subsequent observations of other patients with gout have strengthened our earlier assumption, that it is doubtful whether a normal period of significant duration is ever observed in patients with gout. The failure to obtain a control period necessitated certain assumptions, which will be discussed below.

In addition to the specific medicine that was administered during each cycle, sedatives and hypnotics were given. These are enumerated in the tables for the respective patients. The action of all of the drugs used in this study on the acid- base excretion was investigated in F. M. during a period of freedom from symptoms. The changes in the water and salt metabolism following the administration of these drugs may be neglected for the present discussion and will be presented elsewhere.

The electrolyte balance for the patient $F . M$.

The paroxysms of acute gout in this patient were very frequent, and the data obtained from the several studies that extended over many weeks describe a continual change of the internal environment of the body. In Tables I, II, and III are given the pertinent data of the electrolyte balance for a 12-day cycle, chosen because it seemed to be typical. Changes of varying magnitude were observed in other cycles, but this cycle has the advantage of showing most of the variations

TABLE II

Electrolytes excreted in the stools and withdrawn in the blood on the patient F.M.

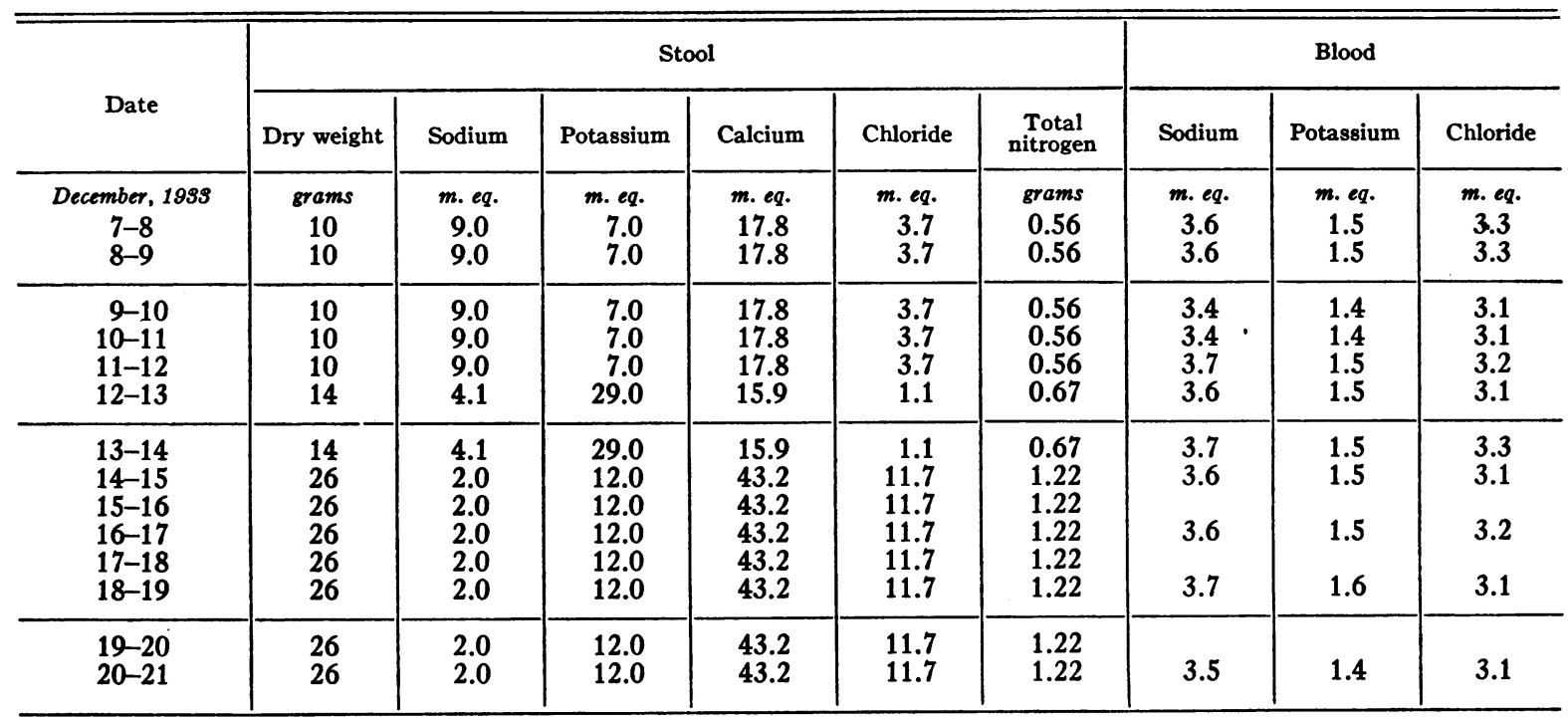

TABLE III

Summary of certain balance data obtained on the patient F.M.

\begin{tabular}{|c|c|c|c|c|c|c|c|c|c|c|c|c|}
\hline & \multicolumn{3}{|c|}{ Prodromal period } & \multicolumn{3}{|c|}{ Attack period } & \multicolumn{3}{|c|}{ Recovery period } & \multicolumn{3}{|c|}{ Total of the three periods } \\
\hline & $\underset{\text { take }}{\text { In- }}$ & $\begin{array}{l}\text { Out- } \\
\text { put }\end{array}$ & $\underset{\text { balance }}{\text { Daily }}$ & $\underset{\text { take }}{\text { In- }}$ & $\begin{array}{l}\text { Out- } \\
\text { put }\end{array}$ & $\begin{array}{c}\text { Daily } \\
\text { balance }\end{array}$ & $\underset{\text { take }}{\text { In- }}$ & $\begin{array}{l}\text { Out- } \\
\text { put }\end{array}$ & $\underset{\text { balance }}{\text { Daily }}$ & $\begin{array}{l}\text { In- } \\
\text { take }\end{array}$ & $\begin{array}{l}\text { Out- } \\
\text { put }\end{array}$ & $\begin{array}{c}\text { Daily } \\
\text { balance }\end{array}$ \\
\hline 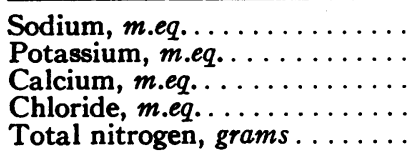 & $\begin{array}{c}144 \\
153 \\
80 \\
152 \\
19.1\end{array}$ & \begin{tabular}{|c|}
269 \\
137 \\
49 \\
278 \\
18.3
\end{tabular} & $\begin{array}{r}-62 \\
+8 \\
+15 \\
-63 \\
+0.4\end{array}$ & $\begin{array}{r}175 \\
216 \\
119 \\
187 \\
26.5\end{array}$ & $\begin{array}{c}270 \\
249 \\
78 \\
290 \\
43.4\end{array}$ & $\begin{array}{l}-24 \\
-8 \\
+10 \\
-25 \\
-4.2\end{array}$ & \begin{tabular}{|c|}
427 \\
449 \\
256 \\
425 \\
56.7
\end{tabular} & $\begin{array}{c}179 \\
388 \\
261 \\
288 \\
51.4\end{array}$ & $\begin{array}{l}+41 \\
+10 \\
-1 \\
+23 \\
+0.9\end{array}$ & $\begin{array}{l}746 \\
818 \\
455 \\
764 \\
102.3\end{array}$ & $\begin{array}{l}718 \\
774 \\
388 \\
856 \\
113.1\end{array}$ & $\begin{array}{l}+2.3 \\
+3.7 \\
+5.5 \\
-7.6 \\
-0.90\end{array}$ \\
\hline
\end{tabular}


noted in the blood and urine during any period of study.

The prodromal period began December 7th and lasted 48 hours. On the first day of this period the patient had no symptoms of acute gout and his temperature did not exceed $37.3^{\circ} \mathrm{C}$. A urinary output of 2,035 cc., 25 per cent above normal, was the first warning of an impending attack. The normal excretion by this patient during the last 3 days of the recovery period and by 3 individuals without gout on a similar diet at the same season of the year was about $1,600 \mathrm{cc}$. The increased urinary output preceding an acute attack was as obvious to the patient as it was to us. This diuresis was accompanied by an increased total excretion of $\mathrm{Na}$ and $\mathrm{Cl}$, as well as an increased concentration of both ions. The excretion of phosphate, urate, and total nitrogen in the urine was increased in amount, but their concentrations remained essentially unchanged. The total excretions of the other constituents analyzed were not increased.

The second and last day of the prodromal period of this cycle the patient had mild symptoms of gout. He had a slight pain in the proximal phalangeal joint of the right big toe, but he was ambulatory throughout the day. The white blood count was 9,500 , and his temperature did not exceed $37.3^{\circ} \mathrm{C}$. His weight had increased $0.5 \mathrm{kgm}$. even though the urinary output was $2,950 \mathrm{cc}$. The increased urinary excretion of $\mathrm{Na}$ and $\mathrm{Cl}$, observed on the preceding day, reached a maximum of 124 m.eq. and 135 m.eq. respectively. The intake of these substances on this day was 72 m.eq. and 76 m.eq. respectively, which gave a negative balance of more than 50 m.eq. for each ion. Increased excretions of lesser magnitude were observed in the other urinary constituents. The $\mathrm{K}$ excretion increased $30 \mathrm{~m}$. eq. and the titratable acid and phosphate increased $10 \mathrm{~m} . \mathrm{eq}$. The excretion of uric acid increased $3 \mathrm{~m} . e q$. The excretion of all other constituents except $\mathrm{NH}_{4}$ and titratable acid was greater than was observed on any other day during the cycle. The $\mathrm{pH}$ of the urine was unchanged.

The attack period began the third morning of the cycle. The proximal phalangeal joint of the left big toe was involved in addition to that of the right big toe. The patient was confined to his bed, but his appetite remained good, and all of the diet was consumed. Though the fluid intake was increased $200 \mathrm{cc}$., the urinary volume was $760 \mathrm{cc}$. less than on the previous day, and the weight was decreased $0.5 \mathrm{kgm}$. The concentration of $\mathrm{Na}$ and $\mathrm{Cl}$ in the urine increased, but the amounts excreted were 10 m.eq. less. The amount of $\mathrm{NH}_{4}$ excreted was unchanged, while the $\mathrm{pH}$ increased to 5.5. Thus on the first day of severe symptoms the pronounced changes in the electrolyte balance had passed a maximum and were rapidly diminishing.

The symptoms continued unabated the fourth day. In addition to the toes, the right sacroiliac joint and right knee were involved. The appetite began to wane for the first time during this cycle, and the intake of food was diminished by one-half. The white blood cell count increased to 13,000 , and the rectal temperature to $38.8^{\circ} \mathrm{C}$. This was the highest temperature observed during the cycle. Clinically, the symptomatic response by this patient on this day was the most marked of any during the cycle. In spite of the severity of symptoms, the excretion of electrolytes and water was less than on any day previously discussed. The urinary volume had decreased to $1,625 \mathrm{cc}$., and the $\mathrm{K}$ excretion was within 4 m.eq. of the intake. The excretions of $\mathrm{Na}$ and $\mathrm{Cl}$ had decreased about 20 m.eq., but were appreciably above the intake because of the lessened ingestion of food. The other constituents were all decreased in amount. Colchicin was started in the morning of this day, but diarrhea resulting from this drug did not begin until 24 hours afterward. It is conceivable that the excretion of electrolytes was appreciably influenced by the fluid drawn into the intestines before the onset of diarrhea.

The third morning of the attack period, the fifth day of the cycle, was associated with a partial alleviation of symptoms. The only new site of involvement was the left Poupart's ligament. Colchicin medication was continued only through the morning. Late in the afternoon diarrhea began, and 3 stools were passed before the patient retired for the night. Although the diarrhea was associated with subsiding symptoms, the patient's appetite remained poor and the intake of food was even less than on the previous day. The urinary volume of $920 \mathrm{cc}$. was the smallest observed during the cycle. The excretion of $\mathrm{Na}$ and $\mathrm{Cl}$ con- 
tinued to decrease, while the excretion of $\mathrm{K}$ remained unchanged.

The sixth day of observation, the last day of the attack period, the rectal temperature was normal. The white blood cell count was 8,650 , and the body weight had decreased $1.6 \mathrm{kgm}$. Diarrhea persisted, but symptoms of the acute attack had disappeared, and the food intake was increased to the amount taken before the acute symptoms began. The urinary volume was $1,530 \mathrm{cc}$, yet some of the constituents were excreted in amounts far below those observed in the prodromal period. The total $\mathrm{Na}$ excretion on this day was only 4.4 m.eq., compared with 124 m.eq. four days previously, and the $\mathrm{Cl}$ excretion was 125 m.eq. less than the maximum of 135 m.eq. The excretion of $\mathrm{K}$ was decreased by one-half. The other electrolytes showed little or no variation. On this day the urinary $\mathrm{pH}$ was 5.1 , the lowest observed during the cycle.

The recovery period began on the 7 th day of the cycle and continued for 6 days. During this period the rectal temperature did not rise above $37.3^{\circ} \mathrm{C}$., nor did the white blood count reach 9,000 . The first 2 days of this period, the urinary volume was below the amount for the last 4 days. The urinary $\mathrm{pH}$ remained between 5.3 and 5.5. The excretion of $\mathrm{Na}$ was 4.6 m.eq. on the first day of the period, which was approximately the same as that excreted on the previous day. The excretion of $\mathrm{Cl}$ had diminished to $7.6 \mathrm{~m} . \mathrm{eq}$. The excretion of $\mathrm{K}$ was $27 \mathrm{~m} . \mathrm{eq}$. Approximately the same amount of $K$ was lost in the stool as was excreted in the urine on this day. In contrast, the amounts of $\mathrm{Na}$ and $\mathrm{Cl}$ in the diarrheal stool were negligible. The excretion of 3.7 m.eq. of uric acid was the lowest of any day described.

The last 4 days of this period, the urinary volume was approximately $1,600 \mathrm{cc}$. daily. The excretion of $\mathrm{K}$ was 55 m.eq., and the excretion of Ca was slightly more than 5 m.eq. The daily excretion of $\mathrm{NH}_{4}$ varied between 20 m.eq. and 25 m.eq., and the excretion of phosphate was $5 \mathrm{~m}$.eq. less than the $\mathrm{NH}_{4}$. The end of the recovery period completes this cycle. Two additional days are included in the Tables, which comprise the prodromal period of the following attack. These 2 days, that are a part of the next cycle, are included in order to emphasize the diuresis and the salt loss in the prodromal period and to clarify the duration of the cycle just described.

In addition to the electrolytes excreted in the urine, apreciable amounts were lost in the stools or removed in the samples of blood that were drawn daily (Table II). Atchley, Loeb et al. (6) have shown that stool analyses contribute little to the knowledge of a balance experiment in its entirety. This observation was confirmed by us except on the days when there was diarrhea.

The changes in the whole blood and serum are given in Table IV. The white blood cell count has been discussed above as an aid in the inter-

TABLE IV

Experimental observations on blood and plasma on the patient F.M.

\begin{tabular}{|c|c|c|c|c|c|c|c|c|c|c|c|c|c|c|c|c|}
\hline Date & $\begin{array}{c}\text { Total } \\
\mathrm{CO}_{2}\end{array}$ & Pcon & $\begin{array}{c}\text { Oxy- } \\
\text { gen ca- } \\
\text { pacity }\end{array}$ & $\begin{array}{l}\text { Cell } \\
\text { vol- } \\
\text { ume }\end{array}$ & $\begin{array}{l}\text { White } \\
\text { blood } \\
\text { cells }\end{array}$ & $\begin{array}{l}\text { Uric } \\
\text { acid }\end{array}$ & $\begin{array}{l}\text { Bicar- } \\
\text { bonate }\end{array}$ & $\begin{array}{l}\text { Chlo- } \\
\text { ride }\end{array}$ & $\begin{array}{l}\text { Phos- } \\
\text { phate }\end{array}$ & Urate & $\begin{array}{c}\text { Pro- } \\
\text { teinate }\end{array}$ & $\begin{array}{l}\text { So- } \\
\text { dium }\end{array}$ & $\begin{array}{l}\text { Potas- } \\
\text { sium }\end{array}$ & $\begin{array}{c}\text { Cal- } \\
\text { cium }\end{array}$ & $\begin{array}{l}\text { Total } \\
\text { inor- } \\
\text { ganic } \\
\text { base }\end{array}$ & $\begin{array}{c}\text { Non- } \\
\text { protein } \\
\text { nitro- } \\
\text { gen }\end{array}$ \\
\hline $\begin{array}{c}\text { Decem- } \\
\text { ber, } \\
1983\end{array}$ & $\begin{array}{c}\text { meq. } \\
\text { per } \\
\text { liter }\end{array}$ & $\underset{H g}{m m}$ & $\begin{array}{c}\text { m. eq. } \\
\text { per } \\
\text { liter }\end{array}$ & $\begin{array}{l}\text { per } \\
\text { cent }\end{array}$ & & $\begin{array}{c}\text { mgm. } \\
\text { per } \\
100 \mathrm{cc} .\end{array}$ & $\begin{array}{c}\text { m. eq. } \\
\text { per } \\
\text { liter }\end{array}$ & $\begin{array}{c}\text { m. eq. } \\
\text { per } \\
\text { liter }\end{array}$ & $\begin{array}{c}\text { m. eq. } \\
\text { per } \\
\text { liter }\end{array}$ & $\begin{array}{c}\text { m.eq. } \\
\text { per } \\
\text { liter }\end{array}$ & $\begin{array}{c}\text { meq. } \\
\text { liter }\end{array}$ & $\begin{array}{c}\text { m.eq. } \\
\text { per } \\
\text { liter }\end{array}$ & $\begin{array}{c}\text { m. eq. } \\
\text { per } \\
\text { liter }\end{array}$ & $\underset{\substack{\text { per } \\
\text { liter }}}{\text { m. }}$ & $\begin{array}{c}\text { m. eq. } \\
\text { per } \\
\text { liter }\end{array}$ & $\begin{array}{c}\text { mgm. } \\
\text { per } \\
100 \mathrm{cc} .\end{array}$ \\
\hline $\begin{array}{r}9 \\
10 \\
11 \\
12\end{array}$ & $\begin{array}{l}21.6 \\
21.9 \\
22.3 \\
23.3\end{array}$ & $\begin{array}{l}41.7 \\
37.9 \\
39.6 \\
43.7\end{array}$ & & $\begin{array}{l}47.2 \\
45.2 \\
46.2 \\
47.7\end{array}$ & $\begin{array}{r}14,250 \\
13,000 \\
15,750 \\
8,650\end{array}$ & $\begin{array}{l}7.8 \\
6.8 \\
6.5 \\
9.3\end{array}$ & $\begin{array}{l}24.6 \\
25.4 \\
26.3 \\
27.5\end{array}$ & \begin{tabular}{|r|}
101.6 \\
100.6 \\
96.0 \\
96.3
\end{tabular} & $\begin{array}{l}1.7 \\
1.7 \\
1.6 \\
1.7\end{array}$ & $\begin{array}{l}.73 \\
.67 \\
.64 \\
.80\end{array}$ & $\begin{array}{l}17.1 \\
18.9 \\
15.9 \\
18.2\end{array}$ & $\begin{array}{l}141.2 \\
142.0 \\
140.0 \\
141.2\end{array}$ & $\begin{array}{l}2.9 \\
3.5 \\
2.3\end{array}$ & $\begin{array}{l}5.0 \\
5.1\end{array}$ & $\begin{array}{l}154.7 \\
153.9 \\
151.6\end{array}$ & \\
\hline 20 & 22.5 & 41.5 & & 42.3 & 11,000 & 9.0 & 25.2 & 105.1 & 2.0 & .80 & 18.3 & 141.6 & 7.1 & & 156.5 & 23.4 \\
\hline
\end{tabular}


pretation of the clinical course of the acute attack. The cell volume exhibited minor fluctuations during the attack but fell appreciably during the period of recovery. This significant decrease in cell volume was infrequently observed in the other cycles that were studied. The number of determinations of oxygen capacity was insufficient to aid in the interpretation of this phenomenon. The concentrations in the serum of calcium, inorganic phosphate and urate were not appreciably influenced by the attack of gout. In the complete cycle described at this time there was no increase in the concentration of $\mathrm{K}$ before the attack. In the attack that followed there was an increase in concentration of $\mathrm{K}$ from 4.0 m.eq. to $7.1 \mathrm{~m}$.eq. Such an increase was confirmed in several of the subsequent attacks. The $\mathrm{CO}_{2}$ content of the serum and the concentration of $\mathrm{Cl}$ during the prodromal period were in the normal range, but their changes in concentration during the acute attack reached a magnitude not approached by any other electrolyte except proteinate. The $\mathrm{Cl}$ decreased in concentration from $102.2 \mathrm{~m}$.eq. on the second day of the prodromal period to $96.2 \mathrm{~m} . \mathrm{eq}$. on the last day of the attack period. The $\mathrm{CO}_{2}$ content of the serum increased 2.9 m.eq. over the same period. A decrease of $3 \mathrm{~m}$.eq. in the serum sodium concentration was observed in all of the cycles in which sodium was determined. The con- centrations of $\mathrm{Na}$, total base, $\mathrm{Cl}, \mathrm{CO}_{2}, \mathrm{PO}_{4}$ and urate at the end of the recovery period were all within 1 m.eq. of their concentrations before the onset of symptoms.

The electrolyte balance for the patient $K . H$.

In Table $\mathrm{V}$ are given the various data of the electrolyte balance for this patient during a cycle of gout of 14 days' duration. There are certain features in the response of $\mathrm{K}$. $\mathrm{H}$. that are at variance with the response of F. M. Her weight showed a steady rise of $2.2 \mathrm{kgm}$. during the period observed. The paradoxical gain in weight, observed in F. M. before the attack, was confirmed, but the magnitude of gain was less. Likewise, a diuresis before the onset of symptoms was observed, but the amount was not as large. The maximum amount of urine excreted by $\mathrm{K}$. $\mathrm{H}$. was $2,120 \mathrm{cc}$. on the day of severe symptoms. This volume was $200 \mathrm{cc}$. greater than that of the preceding day and $700 \mathrm{cc}$. greater than that observed on the day before the onset of symptoms. An increased excretion of $\mathrm{Cl}$, from $80 \mathrm{~m} . e q$. to 135 m.eq., accompanied the diuresis. This maximum excretion does not represent as great an excess for K. H. as for F. M., because the chloride intake was somewhat greater. The excretions of urate, phosphate and titratable acid on the days when the diuresis was observed were increased in amount,

TABLE V

Daily observations on the patient $K$. $H$.

\begin{tabular}{|c|c|c|c|c|c|c|c|c|c|c|c|}
\hline \multirow{2}{*}{ Date * } & \multirow{2}{*}{ Gout } & \multirow{2}{*}{$\begin{array}{c}\text { Rectal } \\
\text { tem- } \\
\text { perature }\end{array}$} & \multirow{2}{*}{ Weight } & \multirow{2}{*}{$\begin{array}{c}\text { Intake } \\
\text { Chloride }\end{array}$} & \multicolumn{6}{|c|}{ Urinary constituents } & \multirow{2}{*}{ Period } \\
\hline & & & & & Volume & Chloride & Urate & $\begin{array}{l}\text { Phos- } \\
\text { phate }\end{array}$ & $\underset{\text { monia }}{\text { Am- }}$ & $\begin{array}{c}\text { Titrat- } \\
\text { able acid }\end{array}$ & \\
\hline $\begin{array}{c}\text { A pril, } 1984 \\
15-16 \\
16-17 \\
17-18\end{array}$ & $\begin{array}{c}\text { severity } \\
0 \\
0 \\
0\end{array}$ & $\begin{array}{l}{ }^{\circ} C . \\
37.5 \\
38.0 \\
37.8\end{array}$ & $\begin{array}{l}\text { kgm. } \\
70.7 \\
71.3 \\
71.5\end{array}$ & $\begin{array}{c}\text { m. eq. } \\
116 \\
116 \\
116\end{array}$ & $\begin{array}{c}c c . \\
1510 \\
1820 \\
1450\end{array}$ & $\begin{array}{r}\text { m. eq. } \\
58.2 \\
83.7 \\
77.5\end{array}$ & $\begin{array}{c}m g m . \\
148 \\
168 \\
147\end{array}$ & $\begin{array}{c}m g m . \\
418 \\
325 \\
299\end{array}$ & $\begin{array}{l}\text { m. eq. } \\
13.5 \\
21.0 \\
18.9\end{array}$ & $\begin{array}{l}\text { m. eq. } \\
21.5 \\
19.6 \\
18.2\end{array}$ & Prodromal \\
\hline $\begin{array}{l}18-19 \\
19-20 \\
20-21 \\
21-22 \\
22-23 \\
23-24\end{array}$ & $\begin{array}{c}+ \\
++ \\
+ \\
+ \\
+ \\
+\end{array}$ & $\begin{array}{l}38.0 \\
37.8 \\
37.8 \\
37.7 \\
38.1 \\
37.7\end{array}$ & $\begin{array}{l}72.0 \\
71.9 \\
72.5 \\
72.3 \\
72.3 \\
72.6\end{array}$ & $\begin{array}{l}116 \\
112 \\
112 \\
112 \\
112 \\
112\end{array}$ & $\begin{array}{l}1700 \\
1800 \\
2120 \\
1850 \\
1680 \\
2020\end{array}$ & $\begin{array}{l}90.0 \\
103 \\
135 \\
112.3 \\
111.1 \\
111.2\end{array}$ & $\begin{array}{l}164 \\
182 \\
191 \\
186 \\
190 \\
202\end{array}$ & $\begin{array}{l}442 \\
524 \\
630 \\
512 \\
422 \\
535\end{array}$ & $\begin{array}{l}17.8 \\
18.4 \\
18.5 \\
19.3 \\
18.9 \\
21.0\end{array}$ & $\begin{array}{l}23.2 \\
28.2 \\
27.9 \\
24.9 \\
22.8 \\
26.8\end{array}$ & Attack \\
\hline $\begin{array}{l}24-25 \\
25-26 \\
26-27 \\
27-28 \\
28-29\end{array}$ & $\begin{array}{l}0 \\
0 \\
0 \\
0 \\
0\end{array}$ & $\begin{array}{l}37.8 \\
37.7 \\
37.4 \\
37.9 \\
37.4\end{array}$ & $\begin{array}{l}72.5 \\
72.5 \\
72.8 \\
72.6 \\
72.9\end{array}$ & $\begin{array}{l}117 \\
117 \\
117 \\
117 \\
117\end{array}$ & $\begin{array}{l}1950 \\
2000 \\
2050 \\
1680 \\
1770\end{array}$ & $\begin{array}{r}90.2 \\
101.9 \\
110.8 \\
95.6 \\
94.6\end{array}$ & $\begin{array}{l}179 \\
182 \\
182 \\
181 \\
151\end{array}$ & $\begin{array}{l}520 \\
551 \\
393 \\
390 \\
445\end{array}$ & $\begin{array}{l}19.4 \\
19.9 \\
19.1 \\
17.9 \\
17.6\end{array}$ & $\begin{array}{l}24.3 \\
22.3 \\
25.7 \\
22.9 \\
19.7\end{array}$ & Recovery \\
\hline
\end{tabular}

* The following drugs were given: 19-20, pantopon $20 \mathrm{mgm}$., barbital $300 \mathrm{mgm} . ;$ 22-23, pantopon 20 mgm., colchicin $10 \mathrm{mgm}$.; 23-24, colchicin $14 \mathrm{mgm}$. 
but the concentrations remained unchanged. The excretion of ammonia in the urine from $\mathrm{K} . \mathrm{H}$. was considerably less than in the urine from F. M. and two control subjects. This diminished excretion was probably related to the impaired kidney function. Daily blood samples for complete analyses were not drawn from this subject. In Table VI are given certain data for the whole blood and serum. Evidence of renal insufficiency may be deduced from the persistent elevation of the serum chloride concentration above 110 m.eq. and from the lowering of the serum $\mathrm{CO}_{2}$ content below 23 m.eq.

\section{DISCUSSION}

This study of the quantitative changes associated with an attack of acute gout has yielded pertinent data concerning the disturbance of electrolyte balance in this disease. In one of the patients gout was uncomplicated by any other organic pathology; in the other patient, it was associated with renal damage. The analytical results from these patients were, in all respects, qualitatively similar.

The mass movement of water and sodium chloride before the appearance of symptoms was a constant observation during the 21 cycles studied on F. M. This water and electrolyte shift came later in the attacks studied on K. H. The diuresis from F. M. usually began 24 to 72 hours before the first symptoms of gout were complained of and before any elevation in body temperature was observed. The maximum urinary output was observed directly before or on the day of maximum symptoms and was approximately twice the daily output observed during the recovery period. The return of the urinary volume to the normal level occurred over a period of several days which extended through the recovery period. It should be emphasized here that there was no medication during the prodromal period nor in most instances on the day of maximum diuresis. Any effect on the electrolyte and water balance from the drugs administered may be excluded with the exception of the last days of the attack period.

A diuresis before or early in an attack of gout was first observed by Scudamore (14) and has been amply confirmed by our data. Scudamore did little more than comment upon its occurrence, and he offered no explanation for the phenomenon. Clinically, a diuresis with a loss of body fluid and salt may be spontaneous or may result from experimental therapeutics. It is known that starvation, ketone acidosis, ammonium chloride acidosis, glycosuria, thyroxin and parathormone administration may be associated with an increased urinary output. There is little evidence that any of these factors is involved in the diuresis of acute gout.

The diuresis of adrenal insufficiency is not unlike the spontaneous diuresis of gout. In adrenal insufficiency (15) there is an increased excretion of $\mathrm{Na}$ with a loss of water secondary to the loss of base; likewise, in gout the loss of water ap-

TABLE VI

Experimental observations on blood and plasma on the patient $K . H$.

\begin{tabular}{|c|c|c|c|c|c|c|c|c|c|c|c|c|c|c|}
\hline \multirow[b]{2}{*}{ Date } & \multicolumn{6}{|c|}{ Whole blood } & \multicolumn{8}{|c|}{ True plasma } \\
\hline & $\begin{array}{c}\text { Total } \\
\mathrm{CO}_{2}\end{array}$ & $\begin{array}{l}\text { Oxy- } \\
\text { gen ca- } \\
\text { pacity }\end{array}$ & $\begin{array}{c}\text { Cell } \\
\text { volume }\end{array}$ & Sugar & $\begin{array}{l}\text { Crea- } \\
\text { tinine }\end{array}$ & $\begin{array}{l}\text { White } \\
\text { blood } \\
\text { cells }\end{array}$ & $\begin{array}{c}\text { Bicar- } \\
\text { bonate }\end{array}$ & $\begin{array}{l}\text { Chlo- } \\
\text { ride }\end{array}$ & Sodium & $\underset{\substack{\text { Total } \\
\text { base }}}{\text { banic }}$ & $\begin{array}{l}\text { Phos- } \\
\text { phate }\end{array}$ & $\left|\begin{array}{c}\text { Non- } \\
\text { protein } \\
\text { nitrogen }\end{array}\right|$ & Protein & $\begin{array}{l}\text { Uric } \\
\text { acid }\end{array}$ \\
\hline $\begin{array}{c}\text { April, } \\
1984 \\
15 \\
16 \\
17\end{array}$ & $\begin{array}{c}\begin{array}{c}\text { m. eq. } \\
\text { per } \\
\text { liter }\end{array} \\
20.4\end{array}$ & $\begin{array}{c}\begin{array}{c}\text { m. eq. } \\
\text { per } \\
\text { liter }\end{array} \\
6.72\end{array}$ & $\begin{array}{l}\text { per } \\
\text { cent }\end{array}$ & $\begin{array}{c}\underset{\text { per }}{\operatorname{mgm}} \\
100 \mathrm{cc} . \\
121\end{array}$ & $\begin{array}{c}\underset{\text { mgm. }}{\text { per }} \\
100 \mathrm{cc} . \\
1.7\end{array}$ & $\begin{array}{l}6,250 \\
6,050 \\
6,650\end{array}$ & $\begin{array}{c}\begin{array}{c}\text { m. eq. } \\
\text { per } \\
\text { liter }\end{array} \\
22.9\end{array}$ & $\begin{array}{c}\begin{array}{c}\text { m. eq. } \\
\text { per } \\
\text { liter }\end{array} \\
110.0\end{array}$ & $\begin{array}{c}\begin{array}{c}\text { m. eq. } \\
\text { per } \\
\text { liter }\end{array} \\
142.5\end{array}$ & $\begin{array}{c}\begin{array}{c}\text { m. eq. } \\
\text { per } \\
\text { liter }\end{array} \\
155.5\end{array}$ & $\begin{array}{c}\begin{array}{c}\text { m. eq. } \\
\text { per } \\
\text { liter }\end{array} \\
2.0\end{array}$ & $\begin{array}{c}\text { mgm. } \\
\text { per } \\
100 \mathrm{cc} . \\
38.3\end{array}$ & $\begin{array}{c}\text { grams } \\
\text { per } \\
\text { liter }\end{array}$ & $\begin{array}{c}\text { mgm. } \\
\text { per } \\
100 \text { cc. } \\
\\
8.8 \\
8.5\end{array}$ \\
\hline $\begin{array}{l}18 \\
19 \\
20 \\
21 \\
22 \\
23\end{array}$ & & & & & & $\begin{array}{l}7,250 \\
5,500 \\
5,750 \\
6,250 \\
7,150 \\
6,750\end{array}$ & & & & & & $\begin{array}{l}37.3 \\
34.8 \\
38.1 \\
34.9\end{array}$ & $\begin{array}{l}70.8 \\
66.4 \\
68.3 \\
63.0 \\
68.5\end{array}$ & $\begin{array}{l}8.7 \\
\\
9.1 \\
8.9 \\
8.3 \\
8.8\end{array}$ \\
\hline 24 & & & & & & 6,050 & & & & & & & & 8.2 \\
\hline
\end{tabular}


pears to be secondary to the loss of $\mathrm{Na}$ and $\mathrm{Cl}$. During the prodromal period, the period of increased excretion of these electrolytes, the urinary volume is increased, but during the recovery period there is not a concomitant decrease in volume with the significant decrease in the amount of base. While the introduction of adrenal insufficiency into this discussion presents an interesting analogy, it is not proposed to associate the pathogenesis of gout with a temporary deficiency of the cortical hormone.

A diuresis from a transient disturbance of purine metabolism has not been excluded. Certain purine bodies are known to possess a diuretic action, and one or more of these might be formed in sufficient amounts before the attack of gout to produce an increased urinary output. This explanation associates the diuresis intimately with the generally assumed pathogenesis of the disease.

The increase in body weight on the days of increased urinary output is almost paradoxical. On the second day of the prodromal period F. M. excreted more than 2 liters of urine, while his weight increased $0.5 \mathrm{kgm}$. Dr. J. P. Peters (16) has suggested that this may be a function of a difference in loss from insensible perspiration. Confirmation of this helpful suggestion is being sought at present.

The changes in the whole blood and serum that are associated with an attack of gout are of a lesser order of magnitude than might be anticipated from the data on urinary excretion. The decrease in concentration of serum $\mathrm{Na}$ was only 3 m.eq., while the urinary excretion of $\mathrm{Na}$ decreased from 125 m.eq. to 4 m.eq. The concentration of $\mathrm{Cl}$ in the serum decreased more than that of $\mathrm{Na}$, and with this decrease there was an associated increase of the $\mathrm{CO}_{2}$ content. These changes follow the loss of body fluid and presumably are not inherent in the attack of gout. The elevation of the serum $\mathrm{K}$ concentration that was observed during the prodromal period has not been noted in other diureses except that from adrenal insufficiency. There was no elevation of the serum $\mathrm{Ca}$ concentration during any attack, as was reported by Coates and Raiment (17). The blood sugar concentration was not followed through the cycle described here but was done during a subsequent cycle. The determinations were made because of a possible etiologic relation- ship between gout and diabetes mellitus. The blood sugar concentration on the first day of symptoms was $87 \mathrm{mgm}$. per $100 \mathrm{cc}$. The concentration gradually increased until it reached $111 \mathrm{mgm}$. on the last day of maximum symptoms. During recovery the blood sugar concentration decreased to the level found preceding the attack.

An inquiry into the disturbance of the metabolism of uric acid was not the main object of this study; nevertheless certain data were obtained that are related to this subject. We did not confirm the observations of His (18) and Brugsch (19) of a decrease in the concentration of uric acid in the urine before an attack. The uric acid in the urine from the patient $K$. H. showed no significant change in the concentration during the 14-day cycle. An increased concentration in the urine from F. M. appeared late in the attack period. This may be explained by its occurrence on the day of minimum urinary output. The large daily excretion of uric acid by F. M. and the small excretion by $\mathrm{K}$. $\mathrm{H}$. presented a marked contrast. The average amount excreted by F. M. between attacks was about $800 \mathrm{mgm}$. daily and by $\mathrm{K}$. H. it was $150 \mathrm{mgm}$. to $200 \mathrm{mgm}$. daily. The latter was about one-half the amount of uric acid excreted by two control subjects given a similar diet.

In most discussions of the pathogenesis of gout, the formation and destruction of uric acid have been considered to be of primary significance. The equilibrium of uric acid between blood, tissues and urine and the solubility of sodium urate in these media have been of secondary importance. From the observations of the solubility of sodium urate in vitro, there is little to suggest that its concentration is ever near the maximum solubility in blood or extracellular fluid (20). The concentration of uric acid in the urine, however, is frequently of a sufficient magnitude that its solubility may be influenced by the concentration of the other constituents (21). The reciprocal solubility between urates and sodium chloride as noted by Roberts (22) in aqueous solutions was not observed by us during the attacks studied.

This study of the water and mineral balance associated with attacks of acute gout presents the pathologic physiology of the disease from a different viewpoint than given heretofore. Our purpose is not to place less emphasis upon the disturbance of purine metabolism in gout; rather, 
it is desired that gout should be considered a disease associated with a more comprehensive metabolic disturbance. The changes in the electrolyte balance in F. M., considered significant by us, were probably exaggerated because of the frequency of his attacks. The confirmation of these changes in a second patient with a complicating renal disease was most satisfactory. Various aspects of the pathogenesis of gout have been suggested by this work and either have been studied or are being studied at the present. The inciting of an acute attack by a diuretic and the prevention of the diuresis preceding an attack are included in this study. The influence of various minerals added to the diet has been investigated and will be reported later.

\section{SUM MARY}

1. Two patients have been studied during several attacks of acute gout while on a metabolic regime.

2. Changes in water and salt metabolism were observed as follows:

$a$. A diuresis begins before any clinical or subjective evidence of gout is manifest.

$b$. A negative sodium and chloride balance accompany this diuresis.

c. With the diuresis, there is also an increased excretion of potassium, calcium, ammonia, titratable acid, phosphate and urate.

3. The metabolic processes associated with acute gout are not adequately defined by a description of uric acid metabolism alone.

\section{PROTOCOLS}

Case 1. F. M., a single white man of 20 , entered the Massachusetts General Hospital on August 8, 1932, complaining of polyarticular arthritis. The mother and father denied having had any arthritis or gout. At the age of 6 years, the patient had a pain in his left hip, a diagnosis of tuberculosis was made, and the leg was immobilized for 8 months. Subsequent recovery was satisfactory. When he was 12 , he had an inflammation of several joints which persisted several days. During the next 4 years, a similar attack of short duration recurred yearly. Two years before his admission, he began to have from 3 to 5 attacks annually of polyarticular arthritis. These attacks subsided following administration of salicylates. He was fond of well-prepared food and alcoholic beverages.

On admission to the hospital, this patient was well developed and well nourished. The blood pressure was
150/85. Three subsequent determinations varied between $120 / 70$ and $134 / 76$. His chief complaint was pain in both hip joints. The physical examination revealed nothing unusual except tender hip joints. The eye grounds appeared to be normal. No tophi were found. A tentative diagnosis of atypical recurrent rheumatic fever was made. The laboratory studies were as follows: The red blood count was 5,250,000. The white blood cell count was 16,240. The urine at 5 examinations showed no albumin or sugar, and there were no casts or red cells in the centrifuged sediments. The whole blood uric acid concentration at 5 examinations varied between $4.7 \mathrm{mgm}$. per $100 \mathrm{cc}$. and $9.6 \mathrm{mgm}$. per $100 \mathrm{cc}$. A prostatic smear showed many white blood cells and red blood cells. The electrocardiogram was interpreted as normal. The $x$-rays of the right foot, both hands, both ankle joints, and the pelvis showed no variation from the normal. $\mathrm{He}$ was discharged one month after admission with a diagnosis of gout.

One year later he was re-admitted to the hospital for further study. About 3 months prior to this admission, he had noticed a nodule on the dorsal surface of the left index finger, and one month later a tophus appeared in the lobe of the right ear. He was in the hospital 2 months at this time and had 5 attacks of acute gout.

Two and one-half months later he was admitted to the metabolism ward of the hospital, where he remained about 7 months. On admission at this time he had several tophi that had not been observed previously. One tophus was over the left olecranon bursa, another was over the patellar bursa on the right, and there were several small nodules on the right patellar tendon. The $\mathbf{x}$-rays of his feet, knees, sacroiliac joints, hands, elbows and shoulders appeared normal. His basal metabolism, determined in the periods of freedom from attacks, varied between +1 per cent and +6 per cent. The whole blood uric acid varied between $6.5 \mathrm{mgm}$. and 9.7 mgm. per $100 \mathrm{cc}$. A urinary concentration test and a phenolsulphonephthalein excretion test showed a normal renal response. Crystals were removed from a tophus on the ear that were morphologically similar to those of sodium urate.

January 28, 1935, he was re-admitted to the metabolism ward. Additional tophi were observed over the extensor tendon of the right elbow, over the second phalangeal joint of the third finger of the right hand, and over the left phalangeal joint of the little finger of the right hand. The $x$-rays taken at that time were interpreted as follows: "The left shoulder joint shows faint shadows of calcification in the bursa. The left knee, right ankle, and both feet show degenerative changes about the joints, and there are definite punched-out areas of bone destruction involving the articular margins of the right great toe, the left second toe, and the left patella. The left knee joint space is definitely narrowed. These changes are consistent with gout. The elbows, sacroiliac joints, right knee, and right hand show nothing abnormal. No calcified blood vessel walls are seen."

Clinical diagnosis: gout. 
Case 2. K. H., a widowed white woman of 44, entered the Massachusetts General Hospital on March 29, 1934, complaining of polyarthritis, nervousness, frontal headache and enlargement of her thyroid. Her mother had had rheumatism for many years which had been diagnosed as hypertrophic arthritis. The serum uric acid from her mother at one examination was $3.4 \mathrm{mgm}$. per $100 \mathrm{cc}$. The father of the patient had had mild joint disease which had been diagnosed gout. On one examination his serum uric acid concentration was $7.7 \mathrm{mgm}$. per $100 \mathrm{cc}$.

The patient had her first symptoms of joint disturbance at the age of 14 . Since that time she had had several attacks yearly of low-grade arthritis. When she was 34 years old, a bilateral oophorectomy and a hysterectomy were performed. At the age of 38 , she had pain and swelling in the right great toe which persisted for 4 weeks. One year later, she had her tonsils removed. Three years before admission, she had noticed a progressive enlargement of the thyroid. She had had no symptoms of hyperthyroidism, but complained of drowsiness, loss of hair and slowing of speech. One year before admission, she had an attack of right upper quadrant pain that suggested acute cholecystitis to the examining physician. She had had some frequency and dysuria.

On admission, she was well developed and nourished. A nodular goiter was observed, but there were no signs suggestive of myxedema. There were many lesions of acne rosacea on her face. The eye-grounds were normal. Examination of her joints showed tenderness and pain on motion of the mid-phalangeal joint of the right index finger and bony proliferation about the knee joints. The laboratory studies were as follows: The red blood count was $4,150,000$; the white blood count was 11,000 . The specific gravity of the urine varied between 1.007 and 1.013 in 3 samples collected hourly following 12 hours of abstinence from fluids and food. There was on several determinations a slight trace of albumin in the urine by the nitric acid test. The urinary sediment from 4 catheter specimens included numerous white cells, many bacteria and few red blood cells. No casts were seen. The excretion of $1 \mathrm{cc}$. of phenolsulphonephthalein injected intravenously varied, at the end of 15 minutes after injection, between 0.0 per cent and 8 per cent in 5 different tests. The whole blood uric acid concentration varied between $8.2 \mathrm{mgm}$. and $10.2 \mathrm{mgm}$. per $100 \mathrm{cc}$. The nonprotein nitrogen of the serum was $38 \mathrm{mgm}$. per $100 \mathrm{cc}$. The basal metabolic rate was -20 per cent and -17 per cent during the period of study reported at this time. The $x$-rays were interpreted as follows: "There is a rounded area of destruction at the base of the middle phalanx of the right hand. There is soft tissue swelling in this region, as well as about some of the corresponding bones of the other hand. There is narrowing of the joint spaces in these joints. There are some areas of subcartilage destruction in the corresponding joints of the second left finger. These changes might be produced by gout or chronic infectious arthritis." An x-ray taken of the gallbladder region showed areas of increased density that suggested stones.

Clinical diagnosis : gout, cholelithiasis, cystitis, nodular goiter, secondary anemia and chronic nephritis (gouty kidneys?).

\section{DIETS}

Diet Number 4 was eaten by F. M. and contained the following amounts of foods: farina 25 grams, dates 25 grams, 40 per cent cream 50 grams, grapefruit sections 200 grams, orange sections 200 grams, white bread 85 grams, salt-free butter 50 grams, jelly 10 grams, milk 350 cc., macaroni 25 grams, American cheese 25 grams, corn niblets 100 grams, whole egg 100 grams, potato 100 grams, prunes 50 grams, honey 35 grams, tomato juice 25 grams, penuche containing brown sugar 90 grams, and 40 per cent cream 20 grams, sugar 25 grams, sodium chloride 1.45 grams.

Diet Number 6 was eaten by K. H. and contained the following amounts of foods: corn flakes 40 grams, dates 25 grams, 40 per cent cream 100 grams, grapefruit sections 200 grams, orange sections 200 grams, white bread 85 grams, salt-free butter 50 grams, jelly 10 grams, milk 350 cc., macaroni 25 grams, American cheese 25 grams, corn niblets 100 grams, whole egg 100 grams, potato 100 grams, prunes 50 grams, penuche containing brown sugar 90 grams, and 40 per cent cream 20 grams, sugar 52 grams, sodium chloride 1.45 grams.

\section{BIBLIOGRAPHY}

1. Wollaston, W. H., On gouty and urinary concretions. Phil. Tr., London, 1797, 87, 386.

2. Garrod, A. B., Observations on certain pathological conditions of the blood and urine in gout, rheumatism and Bright's disease. Medico-Chir. Tr., London, $1848,31,83$.

3. Fischer, Emil, Untersuchungen in der Puringruppe. Julius Springer, Berlin, 1907.

4. Grafe, E., Die Krankheiten des Stoffwechsels und ihre Behandlung. Julius Springer, Berlin, 1931.

5. Thannhauser, S. J., Lehrbuch des Stoffwechsels und der Stoffwechselkrankheiten. J. F. Bergmann, München, 1929.

6. Atchley, D. W., Loeb, R. F., Richards, D. W., Jr., Benedict, E. M., and Driscoll, M. E., On diabetic acidosis. A detailed study of electrolyte balances following the withdrawal and reestablishment of insulin therapy. J. Clin. Invest., 1933, 12, 297.

7. Talbott, J. H., and Michelsen, J., Heat cramps: A clinical and chemical study. J. Clin. Invest., 1933, $12,533$. 
8. Folin, O., Standardized methods for the determination of uric acid in unlaked blood and in urine. J. Biol. Chem., 1933, 101, 111.

9. Butler, A. M., and Tuthill, E., An application of the uranyl zinc acetate method for determination of sodium in biological material. J. Biol. Chem., 1931, 93, 171.

10. Jacobs, H. R. D., and Hoffman, Wm. S., A new colorimetric method for the estimation of potassium. J. Biol. Chem., 1931, 93, 685.

11. Hastings, A. B., Sendroy, J., Jr., and Robson, W., Studies of acidosis. XXI. The colorimetric determination of the $\mathrm{pH}$ of urine. J. Biol. Chem., $1925,65,381$.

12. Folin, O., The acidity of urine. Am. J. Physiol., 1903, 9, 265.

13. Duckworth, D., A Treatise on Gout. Charles Griffin Co., London, 1889.

14. Scudamore, C., A Treatise on the Nature and Cure of Gout. Longman, Hurst, Rees, Orme and Brown, London, 1816.

15. Loeb, R. F., Atchley, D. W., Benedict, E. M., and Leland, J., Electrolyte balance studies in adrenal- ectomized dogs with particular reference to the excretion of sodium. J. Exper. Med., 1933, 57, 775.

16. Peters, J. P., Personal communication.

17. Coates, V., and Raiment, P. C., The calcium content of the blood serum in cases of gout. Biochem. J., 1924, 18, 921.

18. His, W., Die Ausscheidung von Harnsäure im Urin der Gichtkranken, mit besonderer Berücksichtigung der Anfallszeiten und bestimmter Behandlungsmethoden. Deutsches Arch. f. klin. Med., 1900, 65, 156.

19. Brugsch, T., Zur Stoffwechselpathologie der Gicht. Ztschr. f. exper. Path. u. Therap., 1905, 2, 619.

20. Bechold, H., and Ziegler, J., Vorstudien über Gicht. III. Biochem. Ztschr., 1914, 64, 471.

21. Gudzent, F., Physikalisch-chemische Untersuchungen über das Verhalten der Harnsauren Salze in Lösungen. Ztschr. f. physiol. Chem., 1908, 56, 150.

22. Roberts, Wm., On the Chemistry and Therapeutics of Uric Acid, Gravel and Gout. Smith, Elder and Co., London, 1892. 